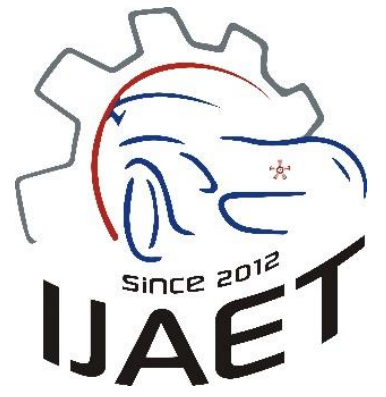

e-ISSN: 2146 - 9067

International Journal of Automotive

Engineering and Technologies

journal homepage: http://ijaet.academicpaper.org

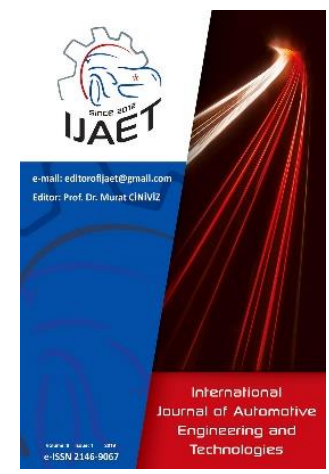

Original Research Article

\title{
Influences of biodiesel fuels produced from highly degraded waste animal fats on the injection and emission characteristics of a CRDI diesel engine
}

\author{
Hüseyin Şanl1 1,2,* \\ ${ }^{1}$ Ford Otosan Ihsaniye Automotive Vocational School, Kocaeli University, 41680, Golcuk, Turkey \\ ${ }^{2}$ Alternative Fuels R\&D Center, Kocaeli University, 41275, Izmit, Turkey
}

\begin{abstract}
ARTICLE INFO
* Corresponding author huseyin.sanli@kocaeli.edu.tr

Received: November 05, 2018

Accepted: April 23, 2019

Published by Editorial Board Members of IJAET

(C) This article is distributed by Turk Journal Park System under the CC 4.0 terms and conditions.
\end{abstract}

\begin{abstract}
In the current study, biodiesel fuels produced from waste chicken fat and waste fleshing oil with high free fatty acid were tested in a four stoke, four-cylinder, water-cooled, turbocharged-intercooled, common rail direct injection (CRDI) diesel engine. Their effects on the injection and exhaust emission characteristics of the test engine were determined and compared with those of petroleum-based diesel fuel (DF) as the reference fuel. Engine tests were performed at different engine loads and constant engine speed of $2000 \mathrm{rpm}$. Injection characteristics showed differences with respect to engine load and fuel type. However, the effects of biodiesel fuels on the injection profiles were more dominant for main injection characteristics such as the start of main injection, end of the main injection, injection amount and injection rate and these effects became more pronounced with increasing engine load. Compared to DF, animal fat based biodiesels had better total hydrocarbon (THC) and carbon monoxide $(\mathrm{CO})$ emissions, but their carbon dioxide $\left(\mathrm{CO}_{2}\right)$ and especially nitrogen oxides $\left(\mathrm{NO}_{\mathrm{x}}\right)$ emissions were higher. In addition, waste fleshing oil-based biodiesel fuel emitted lower emissions than waste chicken fat-based biodiesel.
\end{abstract}

Keywords: Waste Animal Fat, Biodiesel, CRDI Diesel Engine, Injection, Exhaust Emission

\section{Introduction}

Biodiesel fuel, which is a critical and promising alternative fuel, can be produced from various feedstock such as vegetable oils, algae oil, waste frying oils, waste animal fats, soapstock etc. In addition to its advantageous including renewability, sustainability, domestically producibility, it has many technical superiorities and better exhaust emissions compared with petroleum-based diesel fuel (DF) [1-4]. In spite of these positive properties, biodiesel usage amount could not be increased as the desired level because of its higher cost. Nowadays, the price of pure vegetable oils is much higher than that of DF. This high cost, which is the biggest economic obstacle against the commercialization of biodiesel, can be lowered by using waste feedstocks such as waste animal 
fats. Moreover, the use of waste animal fats in biodiesel production prevents the harmful effects against the environment caused by the disposal of these waste materials.

Together with its effect on biodiesel production cost, the feedstock type is also so important in terms of the fuel properties of the produced biodiesel fuel. During the transesterification reaction, the fatty acid composition of the processed feedstock does not significantly change. Thus, the physico-chemical properties of the feedstock are directly decisive on the obtained biodiesel's fuel features. For example, a biodiesel fuel produced from animal fats having a higher level of saturated fatty acids will have higher viscosity, density, cetane number, heating value, better lubricity and oxidative stability but worse cold flow properties such as cold filter plugging point (CFPP) [5-7]. These are the very critical features for usage in diesel engines. Especially modern diesel engines are very susceptible to fuel properties. Because of this, the influences of animal fat based biodiesel fuels on the engine characteristics should be comprehensively investigated.

In the literature, there are a number of articles about the usage of biodiesel fuels obtained from animal fats in diesel engines (although not as many as high-quality vegetable oil-based biodiesels or waste frying oil-based biodiesels). Alptekin et al. [8] performed engine tests with waste animal fat-based biodiesels. In the engine tests, six-cylinder, four-stroke, turbochargedintercooled, direct injection (DI) diesel engine equipped with mechanically controlled in-line type fuel injection system. Engine tests were carried out at a constant engine speed of 1400 rpm and four different engine loads of $150 \mathrm{Nm}$, $300 \mathrm{Nm}, 450 \mathrm{Nm}$ and $600 \mathrm{Nm}$. They have reported that the start of injection was relatively advanced with biodiesels as compared to DF. THC and $\mathrm{CO}$ emissions of biodiesel fuels were lower while their $\mathrm{NO}_{\mathrm{x}}$ and $\mathrm{CO}_{2}$ emissions were higher than those of DF.

Behcet et al. [9] investigated the effects of biodiesel fuels produced from waste fish oil and chicken fat on the exhaust emission characteristics of a single-cylinder, four-stroke, air-cooled, DI diesel engine. Engine tests were conducted at full load and engine speed was selected as 1000, 1500, 2000, and $2500 \mathrm{rpm}$. They have found that biodiesels caused to decrement in the emissions of $\mathrm{CO}, \mathrm{HC}$ and $\mathrm{CO}_{2}$ but increased $\mathrm{NO}_{\mathrm{x}}$ emissions compared to diesel fuel. Exhaust emission profiles of two animal fat-based biodiesel fuels were close to each other.

Shahir et al. [10] operated 2.6 liter, fourcylinder, four-stroke, water-cooled, turbocharged-intercooled, common rail direct injection (CRDI) diesel engine with animal fatbased biodiesel fuels. During engine tests, engine speed was kept constant at $2500 \mathrm{rpm}$ and engine load was increased from $0 \%$ to $100 \%$. They have observed that biodiesel fuels had higher $\mathrm{NO}_{x}, \mathrm{CO}_{2}$, and $\mathrm{HC}$ emissions but lower $\mathrm{CO}$ emissions in comparison to DF.

Despite the abundance of studies on waste animal fat origin biodiesel fuels, this should be strongly stressed that very big portion of these studies was carried out with the old technology diesel engines equipped with mechanicallycontrolled low-pressure fuel injection systems. But, today's commercially available modern diesel engines have electronically-controlled high-pressure fuel injection systems (common rail) and DI combustion chamber type, both of those are very sensitive the fuel quality. When the related literature is reviewed, the lack in the number of studies investigating the usage of highly degraded waste animal fat-based biodiesel fuels on CRDI diesel engines is easily seen.

In this experimental study, it was aimed to reduce this deficiency in the literature partially. For this purpose, biodiesel fuels, which were produced from waste chicken fat and waste fleshing oils having extremely high free fatty acids (FFA), were used in a four-cylinder, fourstroke, water-cooled, turbocharged-intercooled, CRDI diesel engine. The effects of waste animal fat-based biodiesel fuels on the injection and emission characteristics of the test engine were determined and compared with those of DF as the reference fuel. In addition, the change of performance and combustion characteristics with the test fuels were also determined [11], but these data were not given in this article.

\section{Materials and Methods}

Waste chicken fat (WCF) and waste fleshing oil (WFO) which were used as the feedstock in biodiesel production reactions were obtained from Beypiliç Chicken Slaughterhouse in Bolu 
and the solid wastes recycle plant in Istanbul Leather Organized Industry, respectively. Both of waste animal fats were heated at $110{ }^{\circ} \mathrm{C}$ for one hour to remove moisture and then filtered to remove insoluble materials. Some critical physico-chemical properties of the animal fat feedstocks were given in Table 1. DF was purchased from a local gas station.

As seen in the Table, FFA contents of the feedstocks were too high. From the related literature, it is well known that FFAs consume homogeneous alkaline catalysts and cause foaming during transesterification reaction. Because of this, FFA content of any feedstock should be less than $1 \%$ (corresponding to a acid value of about $2 \mathrm{mg} \mathrm{KOH} . \mathrm{g}^{-1}$ ) for alkalinecatalyzed transesterification [12]. In order to decrease the extremely high FFA levels of the feedstocks, the acid-catalyzed pretreatment reactions were carried out for both of them. Pretreatment reaction conditions of $10 \% \mathrm{H}_{2} \mathrm{SO}_{4}$, 30:1 molar methanol ratio, $60{ }^{\circ} \mathrm{C}$ and 1 hour were the same for both feedstock. However, the 1-step pretreatment reaction was enough to decrease the FFA content of WFO to the desired value, but 2-step pretreatment reactions were needed for WCF due to its relatively higher acid value. After pretreatment reactions, alkalinecatalyzed transesterification reactions were performed to produce biodiesel fuels. Transesterification reaction conditions of $1 \%$ $\mathrm{KOH}, 60{ }^{\circ} \mathrm{C}$ and 1 hour were used for both animal fat, but molar methanol ratio was $6: 1$ for WCF and 7.5:1 for WFO.

Table 1. Some physico-chemical properties of WCF and WFO

\begin{tabular}{cccc}
\hline & Unit & WCF & WFO \\
\hline Viscosity $\left(40^{\circ} \mathrm{C}\right)$ & $\mathrm{mm}^{2} . \mathrm{s}^{-1}$ & 53.8 & 51.3 \\
Density $\left(15^{\circ} \mathrm{C}\right)$ & $\mathrm{kg} \cdot \mathrm{m}^{-3}$ & 937.6 & 907.6 \\
Acid Value & $\mathrm{mg} \mathrm{KOH} \cdot \mathrm{g}^{-}$ & 52.3 & 24.7 \\
1 & & 38400 & 39600 \\
Heating Value & $\mathrm{kJ} \cdot \mathrm{kg}^{-1}$ & 400 & 300 \\
Water Content & $\mathrm{ppm}$ & 56.7 & 4.2 \\
Peroxide Value & meq. $\mathrm{kg}^{-1}$ & 55 & 52 \\
Iodine Value & $\mathrm{g} \mathrm{I}_{2 .} .100 \mathrm{~g}^{-1}$ & 85 \\
\hline
\end{tabular}

Table 2. Fuel properties and chemical formulas of DF, CFB, and FOB

\begin{tabular}{|c|c|c|c|c|}
\hline & Unit & $\mathrm{DF}$ & $\mathrm{CFB}$ & FOB \\
\hline Chemical Formula & - & $\mathrm{C}_{12} \mathrm{H}_{23}$ & $\mathrm{C}_{18.6} \mathrm{H}_{35.1} \mathrm{O}_{2}$ & $\mathrm{C}_{18.2} \mathrm{H}_{34.9} \mathrm{O}_{2}$ \\
\hline Viscosity $\left(40^{\circ} \mathrm{C}\right)$ & $\mathrm{mm}^{2} \cdot \mathrm{s}^{-1}$ & 2.96 & 5.30 & 4.70 \\
\hline Density $\left(15^{\circ} \mathrm{C}\right)$ & $\mathrm{kg} \cdot \mathrm{m}^{-3}$ & 832.6 & 889.7 & 876.7 \\
\hline Acid Value & mg KOH.g ${ }^{-1}$ & 0.13 & 0.43 & 0.28 \\
\hline Net Heating Value & kJ.kg-1 & 43013 & 37045 & 37188 \\
\hline Flash Point & ${ }^{\circ} \mathrm{C}$ & 57 & 169 & 168 \\
\hline Iodine Number & g I. $100 \mathrm{~g}^{-1}$ & 11.7 & 95.5 & 53.6 \\
\hline Cetane Number & - & 59.9 & 52.3 & 58.8 \\
\hline CFPP & ${ }^{\circ} \mathrm{C}$ & -16 & 3 & 10 \\
\hline Water Content & ppm & 49.6 & 340 & 310 \\
\hline Copper Strip Corrosion & Degree of corrosivity & No. 1 & No. 1 & No. 1 \\
\hline Monoglyceride & $\%(\mathrm{w} / \mathrm{w})$ & - & 0.02 & 0.06 \\
\hline Diglyceride & $\%(\mathrm{w} / \mathrm{w})$ & - & 0.05 & 0.02 \\
\hline Triglyceride & $\%(w / w)$ & - & 0.06 & 0.20 \\
\hline Free Glycerol & $\%(\mathrm{w} / \mathrm{w})$ & - & 0.008 & 0.01 \\
\hline Total Glycerol & $\%(\mathrm{w} / \mathrm{w})$ & - & 0.03 & 0.05 \\
\hline
\end{tabular}

Table 3. Technical specifications of the test engine

\begin{tabular}{cc}
\hline Engine & 1.9 L, Fiat JTD \\
\hline Type & $\begin{array}{c}\text { Turbocharged, intercooled, four stroke, } \\
\text { water cooled, common rail, direct injection }\end{array}$ \\
$\begin{array}{c}\text { Number of } \\
\text { Cylinder }\end{array}$ & 4 \\
Bore - Stroke & $82 \mathrm{~mm}-90.4 \mathrm{~mm}$ \\
Compression & $18.45: 1$ \\
Ratio & $77.5 \mathrm{~kW}(4000 \mathrm{rpm})$ \\
Max. Power & $205 \mathrm{Nm}(1750 \mathrm{rpm})$ \\
Max. Torque &
\end{tabular}


Engine tests were performed in a four-stroke, four-cylinder, water-cooled, turbochargedintercooled, CRDI diesel engine. Technical specifications of the test engine were given in Table 3. All the engine tests were carried out according to Turkish Standard 1231 (TS 1231Test Code for Internal Combustion Engines). Engine tests were conducted at a fixed engine speed of $2000 \mathrm{rpm}$ and five different engine loads of $50 \mathrm{Nm}(10.47 \mathrm{~kW}), 75 \mathrm{Nm}(15.70 \mathrm{~kW})$, $100 \mathrm{Nm}(20.93 \mathrm{~kW}), 125 \mathrm{Nm}(26.17 \mathrm{~kW})$, and $150 \mathrm{Nm}(31.40 \mathrm{~kW})$.

A hydraulic dynamometer was used to load the engine. The crankshaft position was determined by a crank angle encoder (AVL 365C) fixed over the engine crankshaft pulley. In order to measure the in-cylinder pressure, a glow-plug sensor (AVL GH13P) used for diesel applications was mounted on the cylinder and AVL FlexIFEM brand product was used for data acquisition. A current clamp (Fluke) was used for getting the injection signals. Start and end of injection times were derived from the injector current. AVL IndiCom combustion analysis program was used to obtain and analyze cylinder gas pressure and injection timing data. The temperatures of the intake air, fuel, engine oil and engine coolant were measured by using $\mathrm{K}$ type thermocouples with a digital display. The fuel temperature was controlled by a heat exchanger and kept around $40{ }^{\circ} \mathrm{C} \pm 3{ }^{\circ} \mathrm{C}$ to avoid the physical properties change of test fuels caused by temperature increase. Intake air mass flow was measured by AVL Flowsonix-Air product. Fuel consumption was determined by weighing the fuel used for a period of time on an electronic scale. The exhaust emissions were determined by AVL SESAM FITR exhaust emission analyzer. A schematic layout of the engine setup was shown in Fig. 1.

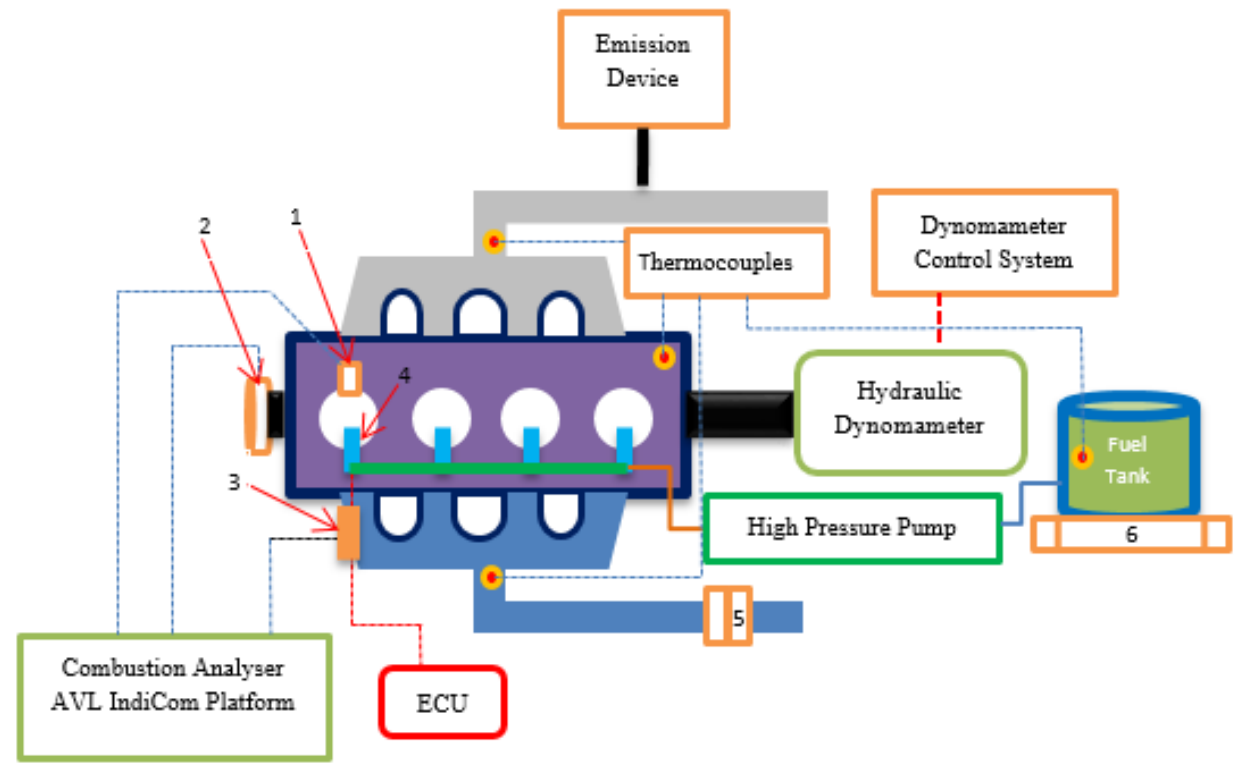

Fig. 1. Schematic view of the experimental setup: (1) AVL Glow-plug sensor, (2) AVL crank angle encoder, (3) Current probe, (4) Common Rail Injector, (5) Air mass flow meter, (6) Electronic scale

\section{Results and Discussion}

The effects of engine load and waste animal fatbased biodiesel fuels on the injection and exhaust emission characteristics of the test engine were determined and compared with those of DF as the reference fuel.

\subsection{Injection characteristics}

The common rail diesel engine used in the engine tests has split injection strategy (one pilot injection-before top dead center (b TDC) and one main injection-after top dead center (a
TDC)). The pilot and main injection timings were obtained by using the injector energizing timings. Injection durations were derived from the injector current (injector energizing duration). Injector opening and closing delays were ignored.

Start of pilot injection (SPI), end of pilot injection (EPI), pilot injection duration (PID), start of main injection (SMI), end of main injection (EMI), main injection duration (MID), injection amount (IA) and injection rate (IR) values were used as the parameters to monitor 
the effects of diesel fuel and waste animal fat based-biodiesel fuels on the injection characteristics of the test engine. The changes in the pilot injection characteristics with engine
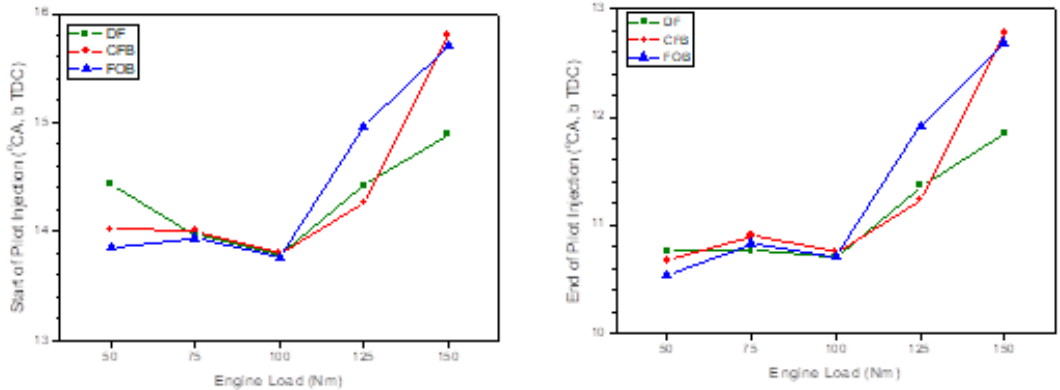

Fig. 2. Change of pilot injection characteristics with engine load
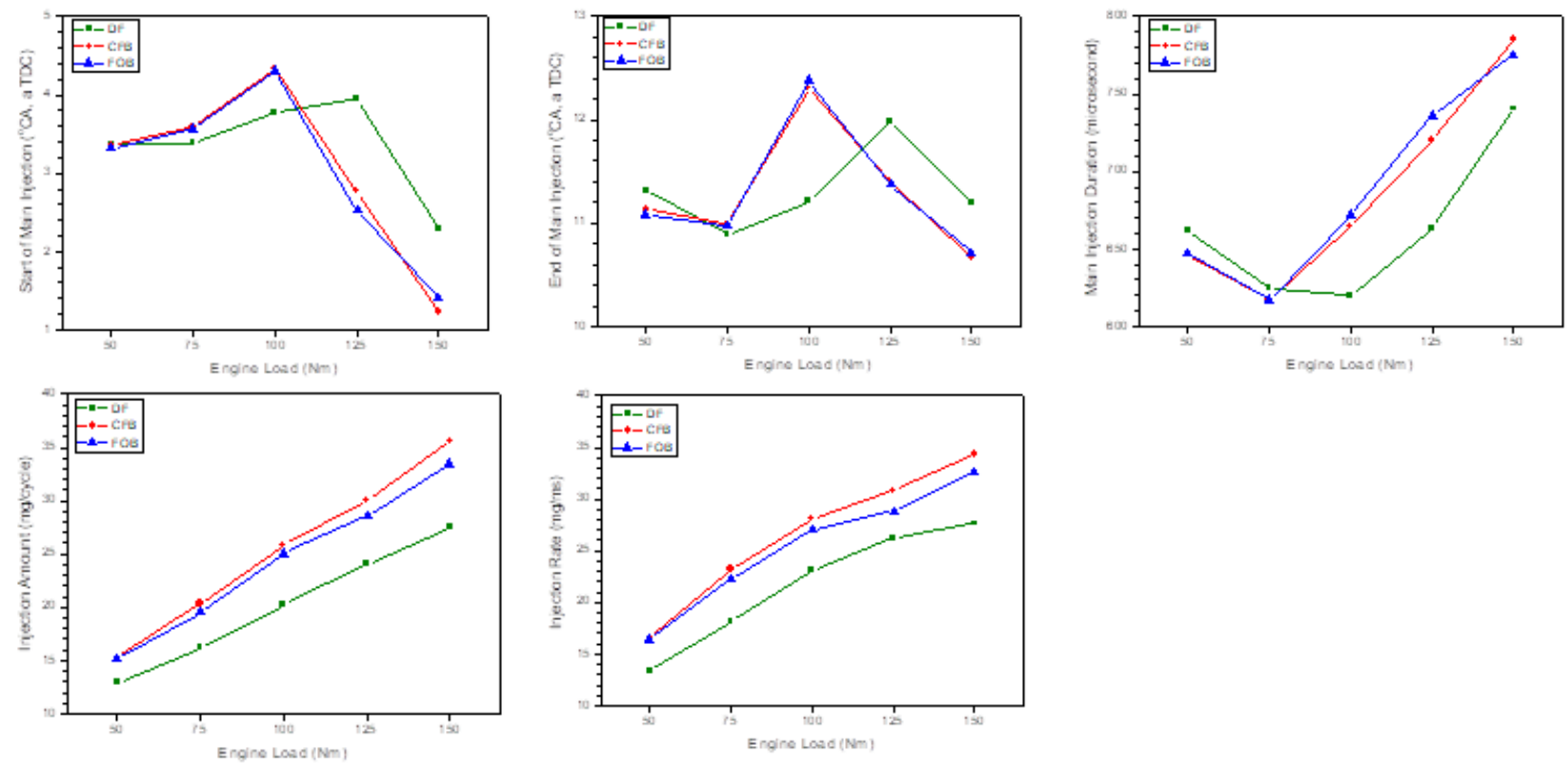

Fig. 3. Change of main injection characteristics with engine load

retarded and then advanced. EPI timings did not significantly change between 50 and $100 \mathrm{Nm}$, but they were advanced at higher loads for all fuels. When the engine load was increased from $100 \mathrm{Nm}$ to $150 \mathrm{Nm}$, the advance determined in the SPI and EPI timings was $1.10^{\circ} \mathrm{CA}$ and 1.15 ${ }^{\circ} \mathrm{CA}$ for DF, $2.08{ }^{\circ} \mathrm{CA}$ and $2.03{ }^{\circ} \mathrm{CA}$ for $\mathrm{CFB}$, $1.94{ }^{\circ} \mathrm{CA}$ and $2.0{ }^{\circ} \mathrm{CA}$ for FOB, respectively.

The difference between the SPI and EPI timings of the test fuels were negligible at low loads (and even they were almost the same at $100 \mathrm{Nm}$ ), but, at the engine loads of $125 \mathrm{Nm}$ and $150 \mathrm{Nm}$, the pilot injection of ester fuels started and ended at earlier crank angles compared to DF. The biggest differences were observed at $150 \mathrm{Nm}$ for both CFB and FOB.

PID values of all test fuels decreased with engine load. However, this decrement was much more marked between $50 \mathrm{Nm}$ and $100 \mathrm{Nm}$.
Although PIDs for DF were higher than those of biodiesels at $50 \mathrm{Nm}$ and $75 \mathrm{Nm}$, the fuels had almost the same PID values at $125 \mathrm{Nm}$ and 150 $\mathrm{Nm}$.

The effects of test fuels and engine load on the main injection characteristics of the test engine were given in Fig. 3. Apart from $125 \mathrm{Nm}$, SMI and EMI timings of all test fuels showed similar trends with engine load. As seen in the related graphs, main injection timings of all test fuels were started and ended at earlier crank angles at high loads. However, this should be said that the change observed in the SMI and EMI was more pronounced for CFB and FOB.

There were not many differences between the SMI and EMI values of DF and ester fuels at 50 $\mathrm{Nm}$ and $75 \mathrm{Nm}$, but they started to differ from each other at increasing engine loads. For instance, at $75 \mathrm{Nm}$, SMI timing of the test fuels 
was detected as $3.38^{\circ}$ a TDC for DF, $3.59^{\circ}$ a TDC for $\mathrm{CFB}$ and $3.56^{\circ}$ a TDC for FOB. However, at $150 \mathrm{Nm}$, SMI timing was $2.3^{\circ}$ a TDC for DF, $1.23^{\circ}$ a TDC for CFB and $1.40^{\circ}$ a TDC for FOB. In addition, this should be underlined that SPI and EPI timings of two biodiesel fuels were very close to each other at all loads tested.

Despite the decrement in MID values of test fuels between the engine loads of $50 \mathrm{Nm}$ and 75 $\mathrm{Nm}$, they started to increase as the engine load was increased. The increment observed in the MID values was higher for $\mathrm{CFB}$ and FOB compared to DF. When the engine load was increased from $50 \mathrm{Nm}$ to $150 \mathrm{Nm}$, the rise in MID value was $11.81 \%$ for DF, $19.82 \%$ for FOB and $21.50 \%$ for CFB. At increasing engine loads, both CFB and FOB had higher MIDs compared to DF. This difference in MID may be due to the lower calorific values of biodiesel fuels as compared to that of DF. As the engine load is increased, the more fuel should be delivered into the engine. So, the electronic control unit (ECU) of the test engine should energize the injectors relatively longer during $\mathrm{CFB}$ and FOB usage.

IA values of all test fuels increased almost linearly with increasing engine load. At all operating conditions, IAs of CFB and FOB were higher than those of DF and this difference become clearer at higher loads. For example, the differences between the IA values of DF and biodiesels, which were $17.43 \%$ for FOB and $18.67 \%$ for CFB at $50 \mathrm{Nm}$, increased to $21.86 \%$ for $\mathrm{FOB}$ and $29.80 \%$ for $\mathrm{CFB}$ at $150 \mathrm{Nm}$. Because the heating contents of CFB and FOB were lower than that of DF, the more fuel should be injected to attain the same engine load and engine speed (as seen in IA values). Similarly, the little difference between the heating values of CFB and FOB (Table 2) showed itself. Namely, the IA value of CFB was higher than that FOB at all engine loads tested and this difference became more pronounced with increasing engine load.

Similar to IA values, IRs of all test fuels inclined with engine load. Since the more energy (more fuel) is needed to raise the engine load, ECU of the test engine increased IR to respond the increment in the engine load for converting the fuel energy to the mechanical work more efficiently. Throughout all operating loads, IR values of $\mathrm{CFB}$ and $\mathrm{FOB}$ were higher compared to DF. Because of their relatively lower heating contents, gas pedal should be pressed more during the usage of biodiesel fuels. Thus, ECU increased the fuel injection pressure and consequently injection rate to inject the higher amount of fuel. Alptekin [13], Indudhar et al. [14], Tziourtzioumis and Stamatelos [15] have also observed higher fuel injection pressures and injection rates when common rail engines were operated with fuels having less heating contents compared to DF. As will be discussed in the exhaust emission characteristics section of this paper, the IR value has a critical influence on combustion and consequently exhaust emissions, especially on $\mathrm{NO}_{\mathrm{x}}$ emissions. Moreover, this should be strongly emphasized that the effect of this parameter drastically increases with increasing engine load [16].

\subsection{Exhaust emission characteristics 3.2.1. CO emissions}

The variation of $\mathrm{CO}$ emissions of test fuels with respect to engine load was illustrated in Fig. 4. As seen in the graph, the change of $\mathrm{CO}$ emissions of test fuels with increasing engine load was the same. Up to $125 \mathrm{Nm}, \mathrm{CO}$ emissions decreased but they increased at $150 \mathrm{Nm}$.

Test fuels' air-fuel ratios (the most critical parameter affecting $\mathrm{CO}$ emissions) were given in Table 4. As can be understood from the decreasing air-fuel ratios, the richer air-fuel mixtures were introduced into the engine with increasing engine load. Despite rich fuel mixtures, the decrement in $\mathrm{CO}$ emissions may be explained by increasing in-cylinder temperatures and pressures. In addition, as the engine load increase, volumetric efficiency and air turbulence improve, injection pressure increases and injection timing advances. The positive effects of these parameters on $\mathrm{CO}$ emission are well known in the literature [1719]. The rise at $150 \mathrm{Nm}$ may be caused by highly rich local zones inside the combustion chamber resulted from non-uniform fuel distribution and short combustion durations. For instance, DF's combustion duration of $21.42{ }^{\circ} \mathrm{CA}$ at $50 \mathrm{Nm}$ decreased to $19.47{ }^{\circ} \mathrm{CA}$ at $150 \mathrm{Nm}$. These data can be seen in Ref. [11] in detail.

At all engine loads tested, biodiesel fuels emitted less CO emissions than DF. Compared to DF as the reference fuel, FOB had $8.27 \%$, 
$24.11 \%, \quad 11.83 \%, \quad 12.07 \%$ and $13.70 \%$ reductions (on average 13.99\%) at $50 \mathrm{Nm}, 75$ $\mathrm{Nm}, 100 \mathrm{Nm}, 125 \mathrm{Nm}$ and $150 \mathrm{Nm}$ while CFB had $4.08 \%, 16.82 \%, 10.44 \%, 6.95 \%$ and $5.25 \%$ (on average $8.71 \%$ ) reductions at corresponding engine loads. Despite their lower air-fuel ratios (meaning richer mixtures) and relatively shorter combustion durations, the lower $\mathrm{CO}$ emissions of animal fat-based biodiesels may be resulted from their molecular oxygen contents. Moreover, ECU of a diesel engine increases the fuel injection pressure and advances the start of injection (as can be seen in the related figures) as a result of the position of the gas pedal (when an engine is powered with lower heating content fuels, the gas pedal should be pressed more to obtain the same operating conditions). These parameters may cause to decrement in $\mathrm{CO}$ emission.

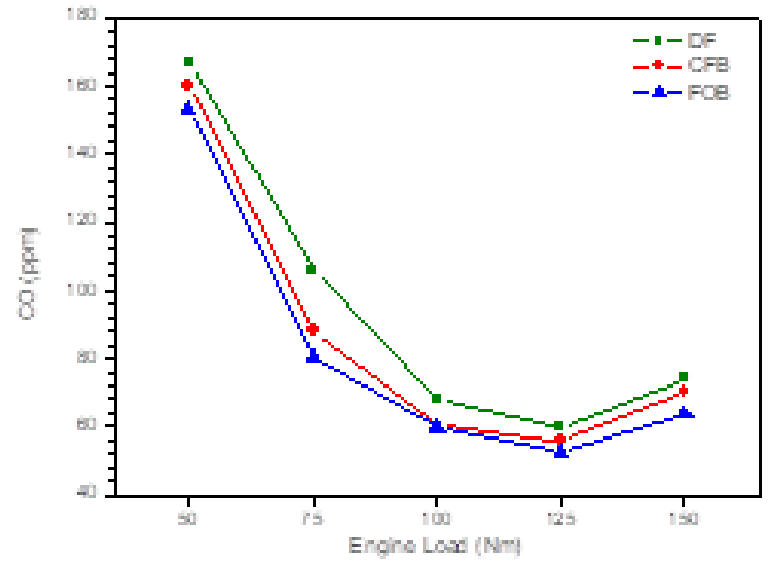

Fig. 4. Comparison of $\mathrm{CO}$ emissions

Table 4. Air-fuel ratios of the test fuels

\begin{tabular}{cccccc}
\hline & 50 & 75 & 100 & 125 & 150 \\
& $\mathrm{Nm}$ & $\mathrm{Nm}$ & $\mathrm{Nm}$ & $\mathrm{Nm}$ & $\mathrm{Nm}$ \\
\hline DF & 37.54 & 30.67 & 26.51 & 23.11 & 19.97 \\
FOB & 33.72 & 27.66 & 22.71 & 20.89 & 18.80 \\
$\mathrm{CFB}$ & 33.37 & 26.51 & 22.05 & 19.87 & 17.65 \\
\hline
\end{tabular}

When the biodiesels were compared to each other, it is seen that FOB had lower $\mathrm{CO}$ emissions than those of $\mathrm{CFB}$ throughout all engine loads tested. The less $\mathrm{CO}$ emissions of FOB may be emanated from its relatively lower viscosity and density values both of which improve the atomization quality and so result in effective air-fuel mixture formation and better combustion.

\subsubsection{THC emissions}

Similar to $\mathrm{CO}, \mathrm{HC}$ emissions indicate insufficient and poor combustion. But, in addition to the air-fuel ratio, the speed of chemical reactions affecting the regional combustion chamber temperatures and so leading to flame quenching is also critical for the formation of $\mathrm{HC}$ emissions [20]. If the hydrocarbons contain methane, they are defined as THC emissions. The change of THC emissions of test fuels with engine load was given in Fig. 5.

THC emissions of all test fuels decreased as the engine load was increased. However, this decrease was more obvious between $50 \mathrm{Nm}$ and $75 \mathrm{Nm}$. The decrement in THC emissions between the lowest and the highest engine loads tested was $34.37 \%$ for DF (from $61.42 \mathrm{ppm}$ to $21.11 \mathrm{ppm}$ ), $26.33 \%$ for CFB (from $52.62 \mathrm{ppm}$ to $38.77 \mathrm{ppm}$ ) and $26.22 \%$ for FOB (from 50.45 ppm to $37.22 \mathrm{ppm}$ ). This declining trend seen in THC emissions with increasing engine load may be resulted from more effective air-fuel mixture formation thanks to higher fuel injection pressure (finer fuel droplets), better turbulence (strong air movement) and increased in-cylinder temperatures (speed evaporation process).

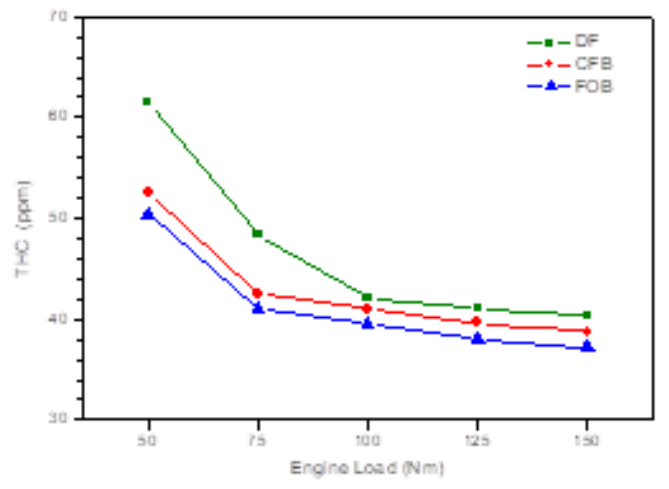

Fig. 5. Comparison of THC emissions

As seen in the figure, biodiesel fuels emitted less THC emissions than DF at all engine loads. The average decrease was $10.87 \%$ for FOB and $7.31 \%$ for CFB. This better THC emission may be caused by their oxygen availability. In addition, higher fuel injection pressure and increasing injection advance obtained with biodiesels should also be considered. Similar to CO emission results, FOB had less THC emissions compared to CFB. This situation might be resulted from FOB's relatively lower viscosity and density than those of CFB. The lower viscosity and density mean the better atomization and consequent finer fuel droplets form more homogeneous mixture inside the 
combustion chamber, resulting in the more complete combustion and so the less THC emissions.

\subsection{3. $\mathrm{CO}_{2}$ emissions}

The change of $\mathrm{CO}_{2}$ emissions of test fuels was depicted in Fig. 6. As seen in the figure, $\mathrm{CO}_{2}$ emissions of all test fuels increased in line with engine load. Higher in-cylinder temperatures, more fuel consumption, higher fuel injection pressure and better air turbulence attained at higher engine loads might result in higher $\mathrm{CO}_{2}$ emissions. When the engine load was increased from $50 \mathrm{Nm}$ to $150 \mathrm{Nm}$, the rise in $\mathrm{CO}_{2}$ emissions was measured by $79 \%$ for DF (from $4.67 \%$ to $8.36 \%$ ), $81.69 \%$ for FOB (from $4.86 \%$ to $8.83 \%$ ) and $83.72 \%$ for CFB (from $4.79 \%$ to $8.80 \%)$.

In comparison to DF as the reference fuel, biodiesel fuels caused to increase in $\mathrm{CO}_{2}$ emissions throughout all operating conditions. The reason for the worse $\mathrm{CO}_{2}$ emissions of biodiesels may be their higher carbon contents compared to DF (Table 2). In addition, ester fuels' higher fuel consumptions, which were caused by their lower heating values, may also be an influential parameter on their relatively higher $\mathrm{CO}_{2}$ emissions. Also, the oxygen contents of $\mathrm{CFB}$ and $\mathrm{FOB}$ can improve the combustion efficiency leading to higher $\mathrm{CO}_{2}$ concentration. In comparison to $\mathrm{DF}$, the average increase in $\mathrm{CO}_{2}$ emissions was $5.93 \%$ for $\mathrm{FOB}$ and $4.71 \%$ for CFB. When the biodiesel fuels were compared to each other, it is seen that their $\mathrm{CO}_{2}$ emissions were very close to each other at all engine loads tested.

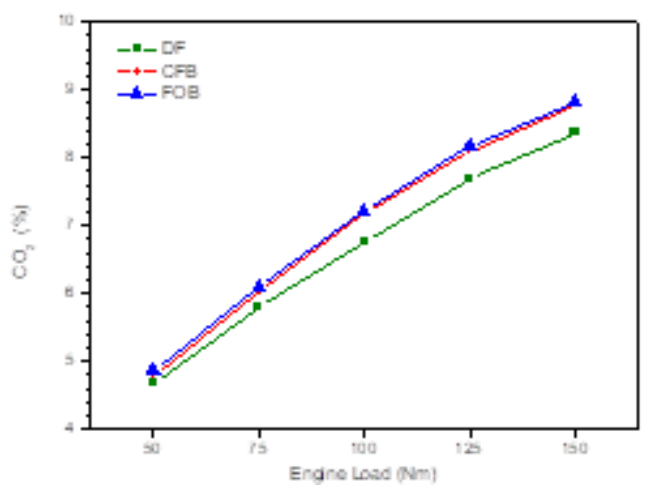

Fig. 6. Comparison of $\mathrm{CO}_{2}$ emissions

\subsubsection{NOx emissions}

Since the high $\mathrm{NO}_{\mathrm{x}}$ emissions are a very big problem especially for diesel engines, they should be investigated in detail. Thermal $\mathrm{NO}_{\mathrm{x}}$ formation is very sensitive to combustion temperature. In addition, combustion duration and local oxygen concentration are also critical parameters on $\mathrm{NO}_{\mathrm{x}}$ emissions [21]. Examining the $\mathrm{NO}_{\mathrm{x}}$ occurring mechanism may be useful in order to understand this emission type and make a correct analysis. According to the Zeldovich mechanism, when the flame temperature of $1800 \mathrm{~K}$ is reached, the air inside the combustion chamber starts to ionize and the following chain reactions occur:

$N_{2}+O \leftrightarrow N O+N$

$\mathrm{N}+\mathrm{O}_{2} \leftrightarrow \mathrm{NO}+\mathrm{O}$

$\mathrm{N}+\mathrm{OH} \leftrightarrow \mathrm{NO}+\mathrm{H}$

In the first reaction, which governs the overall reaction, $\mathrm{O}$ radical attacks $\mathrm{N}_{2}$ to form $\mathrm{NO}$ and $\mathrm{N}$ radical. In the second reaction, which is much faster than the first reaction, $\mathrm{O}_{2}$ is attacked by $\mathrm{N}$ radical to form $\mathrm{NO}$ and $\mathrm{O}$ radical. When the oxygen concentration is insufficient in the combustion media, the second reaction slows down and the third reaction is included [22].

The variations of $\mathrm{NO}_{\mathrm{x}}$ emissions of test fuels were illustrated in Fig 7. As seen, $\mathrm{NO}_{\mathrm{x}}$ concentrations of all test fuels increased almost linearly with engine load. When the engine load was increased from $50 \mathrm{Nm}$ to $150 \mathrm{Nm}$, the rise in $\mathrm{NO}_{\mathrm{x}}$ concentration was $251.87 \%$ (from $303.54 \mathrm{ppm}$ to $1068.08 \mathrm{ppm}$ ) for $\mathrm{DF}, 299.56 \%$ (from $320.47 \mathrm{ppm}$ to $1280.61 \mathrm{ppm}$ ) for FOB, and $314.76 \%$ (from $307.21 \mathrm{ppm}$ to 1274.19 ppm) for CFB. The most important parameters on this drastic $\mathrm{NO}_{\mathrm{x}}$ rise are the increasing incylinder temperatures and pressures attained at high engine loads. Moreover, higher air mass flow into the engine, better turbulence, advanced start of injection and increased fuel injection pressure are also critical factors rising $\mathrm{NO}_{\mathrm{x}}$ emissions [23, 24].

Although $\mathrm{NO}_{\mathrm{x}}$ emissions of all test fuels were very close to each other at $50 \mathrm{Nm}$, biodiesel fuels released higher $\mathrm{NO}_{\mathrm{x}}$ at higher loads and this gap became more apparent with increasing engine load. For instance, the difference between the $\mathrm{NO}_{\mathrm{x}}$ concentrations of $\mathrm{DF}$ and $\mathrm{CFB}$ was $5.58 \%$ at $50 \mathrm{Nm}$ and increased to $19.90 \%$ at $150 \mathrm{Nm}$. This difference for FOB was $1.21 \%$ at $50 \mathrm{Nm}$ and $19.30 \%$ at $150 \mathrm{Nm}$. When the injection characteristics are analyzed it is seen that SMI and EMI timings were very similar at 
$50 \mathrm{Nm}$ but SMI was advanced for biodiesel fuels and their MID values (injection pulse width) were higher than those of DF at higher engine loads. Similar to injection timing, injection amount and injection rate values are also vital parameters on $\mathrm{NO}_{\mathrm{x}}$ emissions. Because the heating contents of $\mathrm{CFB}$ and $\mathrm{FOB}$ are lower than that of DF, ECU must energize the injectors slightly longer to obtain the same engine test conditions. As seen in MID graph, this difference increased with engine load. So, some of the fuel was injected during the heat release and this overlap between the heat release and fuel injection increased as the engine load was increased. This situation may increase $\mathrm{NO}_{\mathrm{x}}$ emissions of biodiesel fuels significantly. Moreover, as mentioned earlier, ECU increases the fuel injection pressure to respond the position of gas pedal. As can be understood from the IA and IR graphs, the difference in the injection pressures of DF and ester fuels increased with increasing engine load. The augmenting effect of fuel injection pressure on $\mathrm{NO}_{\mathrm{x}}$ emissions is well known in the literature [25].

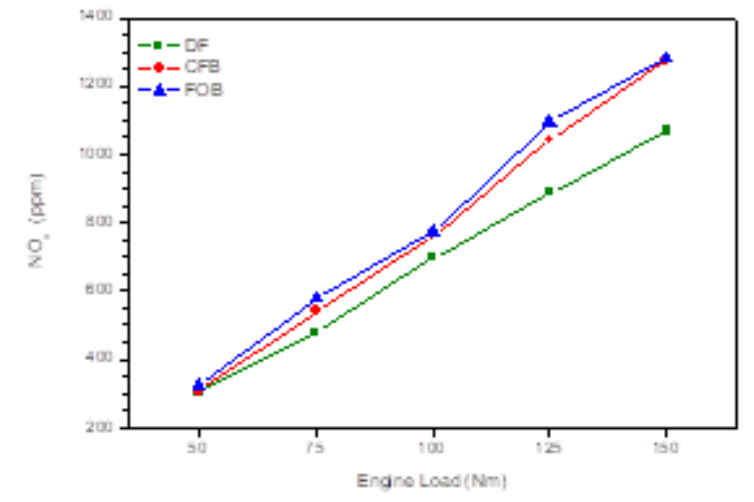

Fig. 7. Comparison of $\mathrm{NO}_{\mathrm{x}}$ emissions

In addition to injection characteristics, the physico-chemical properties of the test fuels should also be considered to interpret their $\mathrm{NO}_{\mathrm{x}}$ emissions. As given in Table 2, the cetane number of DF was higher than those of CFB and FOB. In the literature it is well known that fuels with high cetane number emit relatively less $\mathrm{NO}_{\mathrm{x}}$ emissions [26]. Furthermore, low viscosity, density and iodine value of DF may be influential parameters on its low $\mathrm{NO}_{\mathrm{x}}$ emissions $[27,28]$. Also, molecular oxygen contents of biodiesel fuels might cause to $\mathrm{NO}_{\mathrm{x}}$ rise by improving the combustion phenomenon.

When CFB and FOB are compared to each other it is realized that $\mathrm{NO}_{\mathrm{x}}$ emissions of FOB were higher than those of CFB throughout all operating conditions. Because the injection characteristics were very similar for both biodiesel fuels, this little difference in their $\mathrm{NO}_{\mathrm{x}}$ emissions cannot be explained with this parameter. So, their fuel features should be examined. Despite the better cetane number of $\mathrm{FOB}$, its comparatively higher $\mathrm{NO}_{\mathrm{x}}$ emissions may be caused by lower viscosity and density values which improve the spray formation and result in better combustion and consequently higher in-cylinder temperatures. Moreover, the relatively higher calorific value of FOB compared to that of CFB (Table 2) may also be influential on its higher $\mathrm{NO}_{\mathrm{x}}$ emissions.

\section{Conclusions}

In this experimental study, the effects of biodiesel fuels, which were produced from highly degraded waste chicken fat and waste fleshing oil, on the injection and exhaust emission characteristics of a CRDI diesel engine were determined and compared with those of petroleum-based diesel fuel as the reference fuel.

The start and the end of the pilot and main injection timings were advanced with increasing engine load for all test fuels. But, this advance was more marked with biodiesel fuels. In comparison to DF, both FOB and CFB were injected at earlier crank angles. The effects of biodiesel fuels on the start and the end main injection were higher compared to pilot injection characteristics and this difference increased as the engine load was increased. Main injection duration, injection amount and injection rate of FOB and CFB were higher than those of DF at all operating loads.

These variations in the injection characteristics strongly affected the combustion phenomenon and inevitably exhaust emission characteristics. Biodiesel fuels emitted less CO (the average decrease was $13.99 \%$ for FOB and $8.71 \%$ for $\mathrm{CFB}$ ) and THC emissions (the average decrease was $10.87 \%$ for FOB and $7.31 \%$ for CFB) but higher $\mathrm{CO}_{2}$ (the average increase was $5.93 \%$ for FOB and $4.71 \%$ for $\mathrm{CFB}$ ) and $\mathrm{NO}_{\mathrm{x}}$ emissions (the average increase was $16.37 \%$ for FOB and $12.11 \%$ for CFB).

This significant issue must strongly be pointed out that the injection calibration map of the test engine was not adjusted for biodiesel fuels. 
Namely, CFB and FOB which had different physico-chemical fuel properties were injected via the same strategy calibrated for DF. The ECU of the test engine responded to the position of the gas pedal and advanced the injection timings and increased the fuel injection pressure.

In order to operate a modern CRDI diesel engine more efficiently by using biodiesel fuels, the injection map of ECU should be calibrated according to their fuel properties. For example, injection timings may be retarded and injection pressures may be reduced with biodiesels compared to DF at the same engine operating conditions. With these applications, their higher $\mathrm{CO}_{2}$ and $\mathrm{NO}_{\mathrm{x}}$ emissions may be decreased. The probable deteriorations in the $\mathrm{CO}$ and $\mathrm{THC}$ emissions caused by lower injection pressure and retarded injection timings may be alleviated by the molecular oxygen contents of biodiesel fuels. In addition, biodiesel fuels can be blended with alcohol fuels at certain ratios for increasing the oxygen concentration, decreasing relatively higher viscosity and density, and improving their cold-flow properties. With these applications performed in ECU software and fuel properties, waste animal fat-based biodiesel fuels can successfully be used even in new technology CRDI diesel engines, which are very sensitive to fuel quality, with competitive performance, combustion and emission characteristics.

\section{References}

1. Ramalingam, S., Rajendran, S., Ganesan, P., Gouindasamy, M., Effect of operating parameters and antioxidant additives with biodiesels to improve the performance and reducing the emissions in a compression ignition engine - a review, Renewable and Sustainable Energy Reviews, 81, 775-788, 2018.

2. Hazrat, M.A., Rasul, M.G., Khan, M.M.K., Lubricity improvement of the ultralow sulfur diesel fuel with the biodiesel, Energy Procedia, 75, 111-117, 2015.

3. Wang, Y., Liu, H., Lee, C.F., Particulate matter emission characteristics of diesel engines with biodiesel or biodiesel blending: a review, Renewable and Sustainable Energy Reviews, 64, 569-581, 2016.

4. Ors, I., Kahraman, A., Ciniviz, M.,
Performance, emission and combustion analysis of a compression ignition engine using biofuel blends, Thermal Science, 21, 511-522, 2017.

5. Canakci, M., Sanli, H., Biodiesel production from various feedstocks and their effects on the fuel properties, Journal of Industrial Microbiology and Biotechnology, 35, 431-441, 2008.

6. Sirvio, K., Heikkila, S., Help, R, Niemi, S., Hiltunen, E., Properties of local produced animal-fat based biodiesel and its blend with fossil fuel, Agronomy Research, 16, 1237-1246, 2018.

7. Chakraborty, R., Gupta, A.K., Chowdhury, R., Conversion of slaughterhouse and poultry farm animal fats and wastes to biodiesel: parametric sensitivity and fuel quality assessment, Renewable and Sustainable Energy Reviews, 29, 120-134, 2014.

8. Alptekin, E., Canakci, M., Ozsezen, A.N., Turkcan, A., Sanli, H., Using waste animal fat based biodiesels-bioethanol-diesel fuel blends in a DI diesel engine, Fuel, 157, 245254, 2015.

9. Behcet, R., Oktay, H., Cakmak, A., Aydin, H., Comparison of exhaust emissions of biodiesel-diesel fuel blends produced from animal fats, Renewable and Sustainable Energy, 46, 157-165, 2015.

10. Shahir, V.K., Jawahar, G.P., Suresh, P.R., Vinod, V., Experimental investigation on performance and emission characteristics of a common rail direct injection engine using animal fat blends, Energy Procedia, 117, 283290, 2017.

11. Sanli H., Atık hayvansal yağ kökenli biyomotorin yakıtların ortak hat direkt püskürtmeli bir diesel motorda kullanımının incelenmesi: performans ve yanma karakteristikleri, Pamukkale University Journal of Engineering Sciences, Article in Press, doi: 10.5505/pajes.2018.54715 (in Turkish).

12. Sanli, H., Alptekin, E., Canakci, M., Production of fuel quality ethyl ester biodiesel: 1-Laboratory-scale optimization of waste frying oil ethanolysis, 2-Pilot-scale production with the optimal reaction conditions, Waste and Biomass Valorization, https://doi.org/10.1007/s12649018-0195-z, 2018.

13. Alptekin, E., Emission, injection and combustion characteristics of biodiesel and oxygenated fuel blends in a common rail diesel 
engine, Energy, 119, 44-52, 2017.

14. Indudhar, M.R., Banapurmath, N.R., Rajulu, K.G., Khandal, S.V., Effect of injection timing and injection pressure on the performance of biodiesel ester of hengeoil fuelled common rail direct injection (CRDI) engine, International Journal of Engineering Science and Technology, 7, 37-48, 2015.

15. Tziourtzioumis, D., Stamatelos, A., Effects of a $70 \%$ biodiesel blend on the fuel injection system operation during steady-state and transient performance of a common rail diesel engine, Energy Conversion and Management, 60, 56-67, 2012.

16. Sanli, H., An experimental investigation on the usage of waste frying oil-diesel fuel blends with low viscosity in a common rail DIdiesel engine, Fuel, 222, 434-443, 2018.

17. Gnanasekaran, S., Saravanan, N., Ilangkumaran, M., Influence of injection timing on performance, emission and combustion characteristics of a DI diesel engine running on fish oil biodiesel, Energy, 116, 1218-1229, 2016.

18. Hour, H.G., Masjuki, H.H., Kalam, M.A., Teoh, Y.H., Influence of injection timing and split injection strategies on performance, emissions, and combustion characteristics of diesel engine fueled with biodiesel blended fuels, Fuel, 213, 106-114, 2018.

19. Shamer, P.M., Ramesh, K., Assessment on the consequences of injection timing and injection pressure on combustion characteristics of sustainable fuelled engine, Renewable and Sustainable Energy Reviews, 81, 45-61, 2018.

20. Shirneshan, A., $\mathrm{HC}, \mathrm{CO}, \mathrm{CO}_{2}$ and $\mathrm{NO}_{\mathrm{x}}$ emission evaluation of a diesel engine fueled with waste frying oil methyl ester, ProcediaSocial and Behavioral Sciences, 75, 292-297, 2013.

21. Canakci, M., Sanli, H., An assessment about the reasons of $\mathrm{NO}_{\mathrm{x}}$ rise in biodiesel's exhaust emissions, Journal of Naval Science and Engineering, 3, 81-92, 2005.

22. Miller, R., Davis, G., Lavoie, G., Newman, C., Gardner, T., A super-extended Zeldovich mechanism for $\mathrm{NO}_{\mathrm{x}}$ modeling and engine calibration, SAE Technical Paper, 980781, 1998.

23. Aalam, C.S., Saravanan, C.G., Effects of fuel injection pressure on CRDI diesel engine performance and emissions using CCD,
International Research Journal of Engineering and Technology, 2, 1411-1416, 2015.

24. Sayin, C., Gumus, M., Canakci, M., Effect of fuel injection timing on the emissions of a DI diesel engine fueled with canola oil methyl esters-diesel fuel blends, Energy and Fuels, 24, 2675-2682, 2010.

25. Altun, S., Oner, C., Gaseous emission comparison of a compression-ignition engine fueled with different biodiesels, International Journal of Environmental Science and Technology, 10, 371-376, 2013.

26. Reijnders, J., Boot, M., De Goey, P., Impact of aromaticity and cetane number on the soot- $\mathrm{NO}_{\mathrm{x}}$ trade-off in conventional and low temperature combustion, Fuel, 186, 24-34, 2016.

27. Tuccar, G., Tosun, E., Uludamar, E., Investigations of effects of density and viscosity of diesel and biodiesel fuels on NOx and other emission formations, Academic Platform Journal of Engineering and Science, 6, 81-85, 2018.

28. Kahraman, A., Ciniviz, M., Ors, I., Oguz, H., The effect on performance and exhaust emissions of adding cotton oil methyl ester to diesel fuel, International Journal of Automotive Engineering and Technologies, 5, 148-154, 2016. 